REVIEW

\title{
Effective Teaching Strategies in Biological Education: Present and Future Prospects
}

\author{
Noreldaim Elkhidir ${ }^{1 *}$
}

${ }^{1}$ Department of Basic Sciences, Deanship of Preparatory Year and Supporting Studies, Imam Abdulrahman Bin Faisal University, P.O. Box 1982, Dammam 31441, Saudi Arabia

*Corresponding author: Noreldaim Elkhidir: nhelkhidir@iau.edu.sa

\section{OPEN ACCESS}

Citation: Elkhidir N. (2020)

Effective Teaching Strategies in Biological Education: Present and Future Prospects. Open Science Journal 5(4)

Received: $14^{\text {th }}$ June 2020

Accepted: $23^{\text {rd }}$ July 2020

Published: $14^{\text {th }}$ December 2020

Copyright: (C) 2020 This is an open access article under the terms of the Creative Commons Attribution License, which permits unrestricted use, distribution, and reproduction in any medium, provided the original author and source are credited.

Funding: The author(s) received no specific funding for this work

Competing Interests: The author has declared that no competing interests exists.

\section{Abstract:}

Objective: The aim of this study is to explore the diversity of teaching strategies in biological education and expected results on acquisition of knowledge and fulfillment of learning outcomes in an attempt to identify which strategies work best with biology students. Methods: Three databases and search engines were used: Scopus, Google Scholars and Web of Science. Results: The teaching of biological sciences is experiencing evident transformations towards student-centered learning. As educational goals are being modernized in biology at present times. The more simulations and problem-based learning become part of the teaching strategy, the teaching of biology becomes more learner-centered to enhance learners' critical thinking on complex biological processes.

Keywords: Teaching strategies, Biological education

\section{Introduction}

Back in history, traditional classrooms, a teacher's basic tool for displaying lectures are through chalkboards which later on developed to include transparencies with an overhead projector until the advent of computer aided learning tools which greatly transformed instructional methods. Thus, teaching methods is greatly influenced by the available teaching aid. Quite a significant number of universities and colleges throughout the world has been focusing on lecture-based strategies to varying degrees in what is known as Traditional Instructional Methods (TIM) such as lectures, practical lessons and tutorials. Different and diverse teaching approaches have been developed for over the years, the most common of which has been through lectures since the 5th century B.C. Traditional education methods are wholly instructor-centered, whereas the 
students are expected to recite and/or memorize specified content available in the form of written or typed lecture notes.

With the advances in teaching aid and learning objectives, teaching strategies have experienced a significant shift to meet individual student's needs and being more interactive and activity-based learning through collaboration techniques that would require participation and engagement of learners. Thus, many strategies evolved as an attempt to fulfil the objectives of the learning process, by shifting the focus from instructor-driven to learner-centered teaching strategies.

Many universities/colleges do rely on the traditional textbook and memorization approach with poor students' engagement. Some attempts introduced some dynamical models for biological processes which would allow biology students to create their own models for structures. Thus, introducing simulations and modelling modules as teaching methods in biology [1]. Introduction of simulations and modelling is a significant transformation in biology education towards problem-based learning in undergraduate studies [2]. Virtual tools were developed to simulate real biological characteristics on personal computers leading to better understanding of genetics concept by the students [3].

It is evident that modern history has experienced great advances in science at large including technology, medicine and biology. Advances in the field of electron microscopy and associated techniques greatly contributed to the current knowledge on biology at systems, organs, cellular and molecular biology levels. On the other hand, instructional techniques were consequently developed 3D electron microscopy techniques and 3D prototyping technology (3D printing) to generate 3D physical models, ultimately modernizing teaching of cell biology [4]. Further developments in the teaching mode involved the integration of multimedia technology in teaching. It was found that the introduction of multimedia technology in the teaching of biology significantly improved students' achievement $[5,6]$. It is evident that the integration of multimedia technology and teaching has altered instructional strategies in educational institutions. Advances in computer applications and educational softwares significantly boosted the educational process. Interactive cloud computing models has been used to solve various biological problems. Such models further enriched the teaching contents and improved teaching effect [7].

Recently reformers of the teaching of science called for new approaches in which students contribute to the growth of their own biological knowledge as an attempt to shift to student-centered learning in which students could formulate and solve problems about biological systems [8].

It is undoubtedly that teaching strategies are necessarily tailored to the goals of the educational process, the most widely applied of which is what is referred to as Bloom's Taxonomy which divides cognitive objectives into subdivisions ranging from knowledge, comprehension, application, analysis, synthesis to evaluation. These subdivisions are arranged from lowest to highest levels of learning outcomes in the cognitive domain [9].

In this paper we shall focus on which strategies work best with biology students and assess whether specific teaching strategies vary by biology discipline/subject or learning outcome. 


\section{Search methodology}

This review on biological education at universities used three databases to broaden the search. Sources included Scopus, Google Scholar and Web of Science. A search strategy was developed to suit each database features.

On the three databases we adopted PRISMA FRAMEWORK [10] to include articles relevant to the scope of the study. Selection criteria focused on articles published in English during the period 2010-2020. Keywords used included: biological education, teaching strategies, learning outcomes.

- SCOPUS: The search strategy used the keywords (biology AND teaching provided (7,217 records), filtered during the period 2015-2020 to (2.293 records), articles in English (380 records). Figures (1 \& 2) shows a steady increase on biological education since 2015 mostly published by Journal of Biological Education and American Biology Teacher. Out of (380 records), less relevant articles were excluded and $(\mathrm{n}=51)$ were included.

- Google Scholar: The open search using biology AND teaching resulted in 2,680,000 records, of which 119,000 during the period 2015-2020. As Google Scholar does not allow for further filtration and narrowing of search criteria, focus was made on articles on biology teaching strategies and learning techniques. Included articles $(n=33)$.

- Web of Science: Searching the Web of Science with keywords (biology AND teaching/learning techniques/strategies resulted in (611 records of articles published during the period 2010-2020, $29.8 \%$ of which on education scientific disciplines.

Identified records were then screened, duplicates removed and assessed for eligibility. By the end of the search process a total of (28) records were included in the review covering SCOPUS $(n=11)$, Google scholar $(n=12)$ and Web of Science $(n=5)$.

\section{Documents by year}

\section{Scopus}

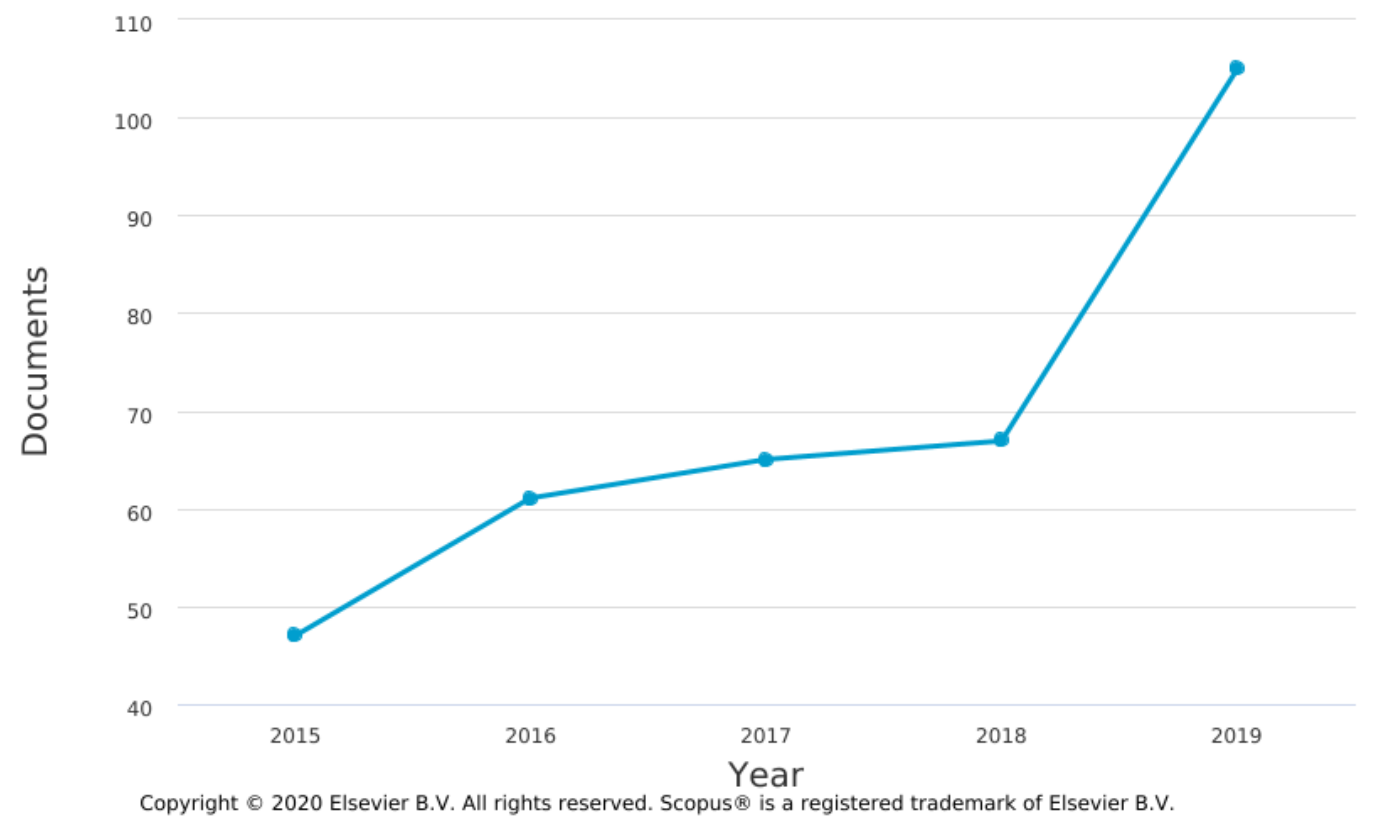

Figure (1): Scopus Articles on Biological Education by Year 
Documents per year by source

Compare the document counts for up to 10 sources.Compare sources and view CiteScore, SJR, and SNIP data

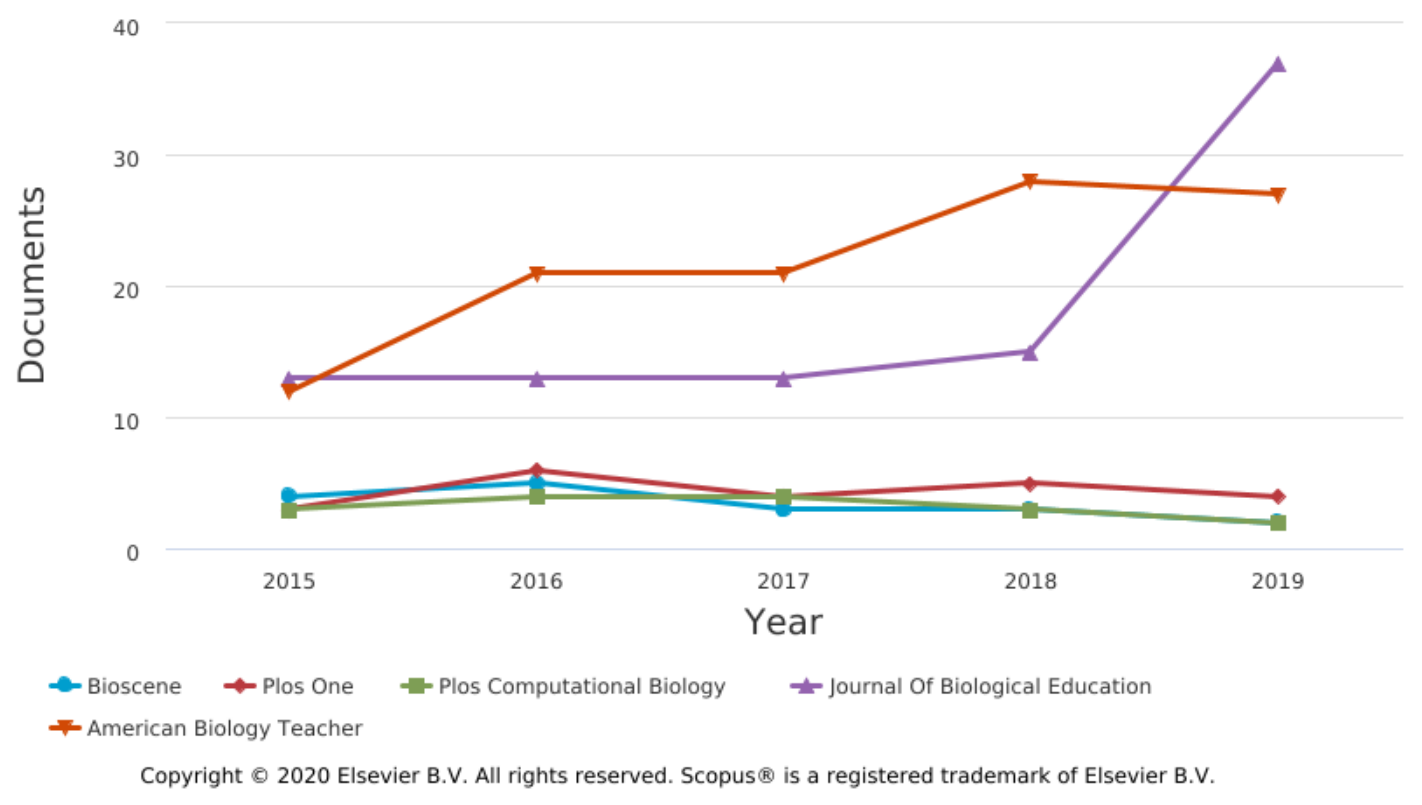

Figure (2): Scopus Articles on Biological Education by Source and Year

\section{Results and discussion}

During the present decade, learning objectives and techniques are undergoing significant transformations and advances from traditional educational methods which reflected poor students' engagement towards more interactive learnercentered methods to achieve learners' engagement which showed a significant positive effect ( $\mathrm{p}=0.0001-0.0025)$ on students' knowledge, attitude and psychomotor skills [11].

Student-centered teaching strategies has recently been adopted in higher education institutions in response to calls for reforms to improve traditional teaching methods which is characterized by dissemination of instructor knowledge and relies on passive student listening. Such strategies would vary from moderate to extensively student-centered approaches which apply many active-learning pedagogies including consistent formative assessment and cooperative groups. Biology student score significantly higher grades and their views about biology and learning biology improved when extensively student-centered teaching strategies were applied [12].

Role-playing is a useful method for getting biology students involved in the learning process and explore realistic situations by interacting with other colleagues in the classroom, in order to develop experience and trial different strategies. Such a strategy could be adapted to the study of various cells, tissues, organs and organ systems to demonstrate how biological processes are interactive in reality. Replicable applications were made on the study of mitosis [13] and protein synthesis [14] which had a positive effect on students understanding of underlying concepts. Such strategies could as well be adapted to learning several biological concepts and processes. Active learning techniques improved the understanding of genetics course material [15] and improved medical students 
score by 3.0 points in a test of 50 points [16]. Students' focused learning and the development of deeper-learning teaching strategies improves retention of basic concepts [17] and get a better understanding of complex biological processes and interactions [18].

Cooperative learning is a new development in science education including biological sciences where learning is mediated by the students and instructors mostly ac as facilitators. In this type of active learning, biology students are divided in smaller groups to achieve a shared set of goals. Students share their ideas within their groups. Students engagement in cooperative learning results in higher achievement, greater retention and more positive feelings about their active engagement and the subject. The role of instructors in cooperative learning is to structure the cooperation within and between groups at a later stage. In this case, the more the students within a group effectively manage their cooperation, the more academic achievements shall be obtained relative to other groups. Group work increases students' enthusiasm for learning and generates more interests on understanding of the subject and the reflections by group members. Several studies, back in history validate cooperative learning as a major strategy for active learning [19].

Cooperative learning is also applicable in biology practical classes to enable the biology students learn through experimentation, as well as allow the students to think independently while cooperating with their colleagues in the laboratory. A cooperative learning model known as 'jigsaw' was adapted to achieve cooperative learning in biology laboratory setting [20]. Students are carefully organized in smaller groups and grades are assigned to individual students rather than to groups. Cooperative learning differs significantly from individualistic learning [21] in several respects as explained in Table (1). Team-based learning is used in a variety of biology disciplines by dividing the course content into modules in which individual and group assessments, mini-lectures, and thinkpair-share activities to assess adequate understanding of the material [22].

Table (1): Teaching strategies that work best with biology learners

\begin{tabular}{|c|c|}
\hline $\begin{array}{l}\text { Structure of Student- } \\
\text { Student Interactions }\end{array}$ & Common Characteristics \\
\hline Competitive Learning & $\begin{array}{l}\text { - } \quad \text { Students work individually. } \\
\text { - } \quad \text { Students have common learning goals and tasks. } \\
\text { - The instructor grades students using norm-referenced methods } \\
\text { (e.g., curve-based grading). }\end{array}$ \\
\hline Individualistic Learning & $\begin{array}{l}\text { - Students work individually. } \\
\text { - Students have individualized learning goals and tasks, different } \\
\text { from those of other students. } \\
\text { - The instructor grades students using criteria-referenced methods } \\
\text { (e.g., rubric-based grading). }\end{array}$ \\
\hline Cooperative Learning & $\begin{array}{l}\text { - Students work in small groups. } \\
\text { - Students have shared learning goals and tasks within a group } \\
\text { which may be similar or different from other groups. } \\
\text { - The instructor grades students both on their work as a group and } \\
\text { on their individual work. }\end{array}$ \\
\hline
\end{tabular}

Source: Tanner, K., Chatman, L. S., \& Allen, D. (2003). Approaches to cell biology teaching: cooperative learning in the science classroom-beyond students working in groups. Cell biology education, 2(1), 1-5. 
Inquiry-based learning is gaining popularity in science curricula and educational strategies. Learners are strongly invited to actively think about why they expect certain results to happen and how the results can be interpreted [23]. Developed modules help students develop a more integrated understanding of complex biological processes [24] and improve biology conceptual understanding [25]. By inquiry-based learning biology students will be capable of exploring authentic problems using the processes and tools they have learned of the biology disciplines. For inquiry-based learning to be successful the students must possess the basic skills to conduct scientific inquiry to investigate and/or solve a biological question.

As the objectives of learning are being developed through time, more specific educational strategies focus on problem-based learning in organized groups. Problem solving in biological and other sciences require critical thinking is often considered an essential learning outcome of institutions in higher education [26]. More emphasis is needed to provide more active, student-centered in-class instruction and assessments which contain higher-order cognitive set of biological questions. Several models are developed to increase the attention and interest of biology learners in scientific topics and improve their critical thinking skills [27]. Table (2) describes the cognitive process dimensions [28,29]. The overall objective of the learning process focuses more on higher than lower order thinking as the case with traditional teaching methods.

Table (2) Learning Models and Cognitive Process Dimension

\begin{tabular}{|c|c|c|c|}
\hline \multirow[t]{2}{*}{$\begin{array}{l}\text { Learning } \\
\text { model/strategy }\end{array}$} & \multirow[t]{2}{*}{ Common Characteristic } & \multicolumn{2}{|c|}{$\begin{array}{l}\text { Learning objective } \\
\text { (Cognitive Process Dimension) }\end{array}$} \\
\hline & & $\begin{array}{l}\text { Cognitive Process } \\
\text { Dimension }\end{array}$ & domains of learning \\
\hline $\begin{array}{l}\text { Inquiry-based } \\
\text { learning }\end{array}$ & $\begin{array}{l}\text { More professional construction of } \\
\text { knowledge including: } \\
\text { Engagement, Exploration, } \\
\text { Explanation, Elaboration, } \\
\text { Evaluation }\end{array}$ & $\begin{array}{l}\text { Coordinating } \\
\text { Explaining } \\
\text { Evaluating }\end{array}$ & $\begin{array}{l}\text { Cognitive knowledge } \\
\text { and mental skills } \\
\text { Physical motor skills }\end{array}$ \\
\hline $\begin{array}{l}\text { Problem-based } \\
\text { learning }\end{array}$ & $\begin{array}{l}\text { Learners define their own } \\
\text { learning objectives and use } \\
\text { appropriate problems to enhance } \\
\text { knowledge and understanding }\end{array}$ & $\begin{array}{l}\text { Reasoning, Justifying, } \\
\text { Critical evaluation, Self } \\
\text { directed learning, } \\
\text { Presentation skills }\end{array}$ & $\begin{array}{l}\text { Cognitive knowledge } \\
\text { and mental skills }\end{array}$ \\
\hline $\begin{array}{l}\text { Collaboration } \\
\text { learning }\end{array}$ & $\begin{array}{l}\text { Learning beyond listening, } \\
\text { reading, and memorizing }\end{array}$ & $\begin{array}{l}\text { Retaining complex } \\
\text { concepts }\end{array}$ & $\begin{array}{l}\text { Interactions and social } \\
\text { skills }\end{array}$ \\
\hline $\begin{array}{l}\text { Role-play } \\
\text { learning }\end{array}$ & $\begin{array}{l}\text { Facilitating active learning about } \\
\text { complex, multidimensional issues. }\end{array}$ & $\begin{array}{l}\text { Applying, analysing, } \\
\text { evaluating }\end{array}$ & Interpersonal/Social \\
\hline $\begin{array}{l}\text { Project-based } \\
\text { learning }\end{array}$ & $\begin{array}{l}\text { Learners utilize different kinds of } \\
\text { knowledge }\end{array}$ & $\begin{array}{l}\text { Applying knowledge } \\
\text { Intensive interaction } \\
\text { Information sharing }\end{array}$ & High cognitive skills \\
\hline
\end{tabular}




\section{Conclusions}

The present decade has experienced trending interests on biological education in terms of more focus on learner-centered educational strategies. Incorporation of computer applications and educational technologies, the use of modelling, simulations and interactive learning strategies shifted the emphasis towards cooperative, inquiry and problem-based learning which greatly contributes to the understanding of complex biological processes.

\section{References:}

[1]Helikar, T., Cutucache, C. E., Dahlquist, L. M., Herek, T. A., Larson, J. J., \& Rogers, J. A. (2015). Integrating interactive computational modeling in biology curricula. PLoS Comput Biol, 11(3), e1004131.

[2]American Association for the Advancement of Science (AAAS) (2011) Vision and Change in Undergraduate Biology Education. http://visionandchange.org/. Accessed 20 December 2013.

[3]Guerra-Varela, J., Cabezas-Sainz, P., Yebra-Pimentel, E., Gutiérrez-Lovera, C., Cedrón, V. P., Otero Obarrio, M. A., ... \& Sánchez, L. (2016). "A zebra in the water": Inspiring science in Spain. Zebrafish, 13(4), 241-247.

[4]Augusto, I., Monteiro, D., Girard-Dias, W., dos Santos, T. O., Belmonte, S. L. R., de Oliveira, J. P. \& Nogueira, B. V. (2016). Virtual reconstruction and three-dimensional printing of blood cells as a tool in cell biology education. PloS one, 11(8).

[5]Satyaprakasha, C. V., \& Sudhanshu, Y. (2014). Effect of multimedia teaching on achievement in Biology. International Journal of Education and Psychological Research (IJEPR), 3(1), 43-45.

[6]Li, Y. (2017). Research and application of the teaching mode with the integration of multimedia technology and teaching management. AGRO FOOD INDUSTRY HI-TECH, 28(1), 2764-2768.

[7]Yang, D. L., Guo, T., \& Zhang, L. G. (2015). The application of network in the experimental teaching of food technology based on cloud computing. Advance Journal of Food Science and Technology, 9(10), 789-793.

[8]Fred Janssen \& Arend Jan Waarlo (2010) Learning Biology by Designing, Journal of Biological Education, 44:2, 88-92.

[9]Bloom, B. S. (1956). Taxonomy of educational objectives. Vol. 1: Cognitive domain. New York: McKay, 20-24.

[10]Moher, D., Liberati, A., Tetzlaff, J., Altman, D. G., Altman, D., Antes, G. \& Clark, J. (2009). Preferred reporting items for systematic reviews and meta-analyses: the PRISMA statement (Chinese edition). Journal of Chinese Integrative Medicine, 7(9), 889-896.

[11]Hilvano, N. T., Mathis, K. M., \& Schauer, D. P. (2014). Collaborative Learning Utilizing CaseBased Problems. Bioscene: Journal of College Biology Teaching, 40(2), 22-30.

[12]Connell, G. L., Donovan, D. A., \& Chambers, T. G. (2016). Increasing the use of student-centered pedagogies from moderate to high improves student learning and attitudes about biology. CBE-Life Sciences Education, 15(1), ar3.

[13]Mark A. Wyn Steven J. Stegink. (2000). Role-Playing Mitosis. The American Biology Teacher. 62(5) 378-382.

[14]Stencel, J. \& Barkoff, A. (1993). Protein synthesis: Role-playing in the class-room. The American Biology Teacher, 55(2), 102-103

[15]Smith, M.K., Wood, W.B., Adams, W.K., Wieman, C., Knight, J.K., Guild, N. \& Su, T.T. (2009). Why peer discussion improves student performance on in-class concept questions. Science, 323, $122-124$.

[16]Thaman, R., Dhillon, S., Saggar, S., Gupta, M. \& Kaur, H. (2013). Promoting active learning in respiratory physiology - positive student perception and improved outcomes. National Journal of Physiology, Pharmacy \& Pharmacology, 3, 27-34.

[17]Jones, H., Black, B., Green, J., Langton, P., Rutherford, S., Scott, J., \& Brown, S. (2015). Indications of knowledge retention in the transition to higher education. Journal of Biological Education, 49(3), 261-273.

[18]Van Nuland, M. E., Chen, M., \& England, B. J. (2019). Bringing Plants \& Soils to Life through a Simple Role-Playing Activity. The American Biology Teacher, 81(4), 287-290.

[19]Johnson, D. W., \& Johnson, R. T. (1989). Cooperation and competition: Theory and research. Interaction Book Company.

[20]Colosi, J. C., \& Zales, C. R. (1998). Jigsaw cooperative learning improves biology lab courses. Bioscience, 48(2), 118-124. 
[21]Tanner, K., Chatman, L. S., \& Allen, D. (2003). Approaches to cell biology teaching: cooperative learning in the science classroom-beyond students working in groups. Cell biology education, $2(1), 1-5$.

[22]Wilke, R. R., \& Straits, W. J. (2005). Practical advice for teaching inquiry-based science process skills in the biological sciences. The American Biology Teacher, 534-540.

[23]Schmid, S., \& Bogner, F. X. (2019). Hearing: An Inquiry-Based Learning Module Linking Biology \& Physics. The American Biology Teacher, 81(7), 485-489.

[24]Lubkowitz, M., Koch, K., Weil, C., \& Braun, D. M. (2017). A question-based approach to teaching photosynthesis, carbohydrate partitioning, and energy flow. The American Biology Teacher, 79(8), 655-660.

[25]Kiernan, D. A., \& Lotter, C. (2019). Inquiry-Based Teaching in the College Classroom: The Nontraditional Student. The American Biology Teacher, 81(7), 479-484.

[26]Holt, E. A., Young, C., Keetch, J., Larsen, S., \& Mollner, B. (2015). The greatest learning return on your pedagogical investment: alignment, assessment or in-class instruction? PloS one, 10(9).

[27]Vásquez, E. C., Ramos-Robles, M. I., \& Morales-Linares, J. (2018). The Ecological Interactions Olympiad: A Classroom Activity for Reinforcing Scientific Knowledge. The American Biology Teacher, 80(5), 365-369.

[28]Krathwohl, D. R., \& Anderson, L. W. (2009). A taxonomy for learning, teaching, and assessing: A revision of Bloom's taxonomy of educational objectives. Longman.

[29]Krathwohl, D. R. (2002). A revision of Bloom's taxonomy: An overview. Theory into practice, $41(4), 212-218$. 